\title{
Systemic and local antibodies induced by an experimental inactivated vaccine against bovine herpesvirus type 1
}

\author{
Anticorpos locais e sistêmicos induzidos por uma vacina experimental \\ inativada contra o herpesvírus bovino tipo 1
}

\section{Maria do Carmo Cilento ${ }^{I^{*}}$ Edviges Maristela Pituco ${ }^{\mathrm{I}}$ Ricardo Spacagna Jordão $^{\mathrm{II}}$ Cláudia Pestana Ribeiro ${ }^{\mathrm{I}}$ Moacir Marchiori Filho ${ }^{\mathrm{III}}$ Hélio José Montassier ${ }^{\mathrm{IV}}$}

\begin{abstract}
An experimental inactivated vaccine against bovine herpesvirus-1 (BoHV-1) was produced aiming to evaluate the systemic and local antibody responses in 12 seronegative heifers, after vaccination and revaccination. Serum samples were submitted to virus neutralization assay and to ELISA test for detection of IgG1 and IgG2 isotypes. Nasal secretion samples were submitted to the same ELISA test for detection of IgG1 and IgG2 isotypes. The results showed that moderate to high neutralizing titres and $\operatorname{Ig} G 1$ and $\operatorname{Ig} G 2$ antibody responses were induced after the second vaccination in the serum and in nasal secretions up to 114 days post vaccination. IgG2 antibodies were the prevalent isotype for most of the post-vaccination period. The results indicate that BoHV-1 experimental inactivated vaccine elicited potentially protective IgG1 and IgG2 antibody levels, both in the systemic and mucosal compartments.
\end{abstract}

Key words: BoHV-1, immunoglobulin isotypes, experimental vaccine.

\section{RESUMO}

Uma vacina experimental inativada contra o herpesvírus bovino tipo 1 (BoHV-1) foi produzida com o objetivo de se avaliar a resposta imune humoral local e sistêmica contra o BoHV-1, em 12 novilhas soronegativas, após a vacinação e a revacinação. Os soros foram submetidos à prova de vírus-neutralização para quantificação do título de anticorpos neutralizantes e a um ELISA para detecção de IgGI e IgG2. Os swabs nasais também foram submetidos ao ELISA para detecção de IgG1 e IgG2 na secreção nasal. Os resultados demonstraram que títulos de anticorpos neutralizantes foram induzidos após a revacinação, em níveis moderados a altos, permanecendo em níveis significativos no soro sanguíneo e na secreção nasal até o dia 114 pós-vacinação. O IgG2 foi o isótipo predominante na maior parte do período pósvacinação, tanto na secreção nasal, como no compartimento sistêmico. A vacina experimental inativada contra o BoHV-1 estimulou níveis de anticorpos potencialmente protetores dos isótipos IgG1 e IgG2, tanto no compartimento sistêmico, como nas mucosas.

Palavras-chave: BoHV-1, isótipos de imunoglobulinas, vacina experimental.

\section{INTRODUCTION}

Bovine herpesvirus-1 (BoHV-1) is an important pathogen in cattle, acting either alone or in association with bacterial pathogens to cause a number of clinical diseases, such as infectious bovine rhinotracheitis (IBR), genital lesions and abortions (FLORES, 2007). In countries with a high prevalence of seropositive animals, the main method of controlling IBR is vaccination of susceptible animals to reduce the virus excretion, and to decrease the severity of clinical signs (MUYLKENS et al., 2007; FLORES, 2007).

A number of protective mechanisms against infection with BoHV-1 have been described which essentially depend upon the induction of a wide spectrum of innate and specific mechanisms of cellular and humoral immune responses. Innate inflammatory

'Laboratório de Viroses de Bovídeos, Instituto Biológico. R. Conselheiro Rodrigues Alves, 1252, 04014-002, São Paulo, SP, Brasil. E-mail: mariacilento@uol.com.br. *Autor para correspondência.

II Laboratório de Produção de Imunobiológicos, Instituto Biológico, São Paulo, SP, Brasil.

III Médico Veterinário Autônomo, São Paulo, SP, Brasil.

${ }^{\text {IV }}$ Laboratório de Virologia e Imunologia, Departamento de Microbiologia, Faculdade de Ciências Agrárias e Veterinárias, Universidade Estadual Paulista (UNESP), Jaboticabal, SP, Brasil. 
and cellular reactions are the first response to BoHV-1 infection (JONES \& CHOWDHURY, 2008). Some of the mechanisms such as complement activation are nonspecific, whereas others, such as interferons and early pro-inflammatory cytokines are induced by virus replication and lead to the recruitment and activation of different cells such as macrophages, polymorphonuclear neutrophils and Natural Killer cells in cattle (MUYLKENS et al., 2007; JONES \& CHOWDHURY, 2008). The non-specific activated immune cells are also essential in initiating and regulating the specific immune response to BoHV-1 (BABIUK et al., 1996, MUYLKENS et al., 2007).

Since current inactivated BoHV-1 vaccines generally induce strong humoral but weak cellmediated immune responses, the success of vaccination has been correlated to the ability of neutralizing antibodies to provide protection (MUYLKENS et al., 2007). Indeed, a correlation between neutralizing antibody responses and level of protection has been demonstrated for BoHV-1 (LEMAIRE et al., 1994; VAN DRUNEN LITTEL-VAN DEN HURK et al., 1994; BABIUK et al., 1996). In addition to virus-neutralization, the anti BoHV-1 antibodies can opsonize the virus, activate the complement system, and can mediate the Antibody Dependent Cellular Cytotoxicity (ADCC) (JONES \& CHOWDHURY, 2008). Antibody function in vivo is chiefly linked to immunoglobulin isotype (McGUIRE et al., 1979), e.g. in bovines, IgG1 antibodies interact with macrophages Fc receptors whereas $\operatorname{IgG} 2$ antibodies interact with neutrophils Fc receptors (HOWARD et al., 1980). Anti-BoHV-1 isotype-specific responses were reported and characterized for experimentally infected cattle (GUY \& POTGIETER, 1985; MADIC et al., 1995; BRADSHAW \& EDWARDS, 1996). However, there are no consistent data in the literature describing the role of antibody isotypes, or even their kinetic production profiles, in bovines immunized with anti-BoHV-1 vaccines formulated with suspensions containing inactivated viral particles. The aim of this research was to develop an experimental vaccine against the herpesvirus type 1 (BoHV-1) using the inactivated virus and to evaluate its immunogenicity in bovines by measuring the levels of neutralizing antibodies, as well as quantifying $\mathrm{IgG} 1$ and $\mathrm{IgG} 2$ antibodies in the serum and in nasal secretions, over time, following vaccination and revaccination.

\section{MATERIALS AND METHODS}

Vaccine preparation

The virus strain used in vaccine production and in the virus neutralization test was the Los Angeles
(ATCC-VR 188; USA). MDBK cell line (ATCCCCL-22) was used for virus propagation. Cells were grown in $150 \mathrm{~cm}^{2}$ polystyrene $\mathrm{T}$ flasks (Corning, USA) using Minimum Essential Medium (MEM) (Cultilab, Brazil) supplemented with 5\% foetal bovine serum (Cultilab), with the addition of sodium bicarbonate (Merck, Germany) adjusted to a final $\mathrm{pH}$ 7.0. Sub-cultivations were carried out every $72 \mathrm{~h}$. To produce the vaccine, an initial cellular inoculum of $0.2 \times 10^{6} \mathrm{cells} \mathrm{mL}^{-1}$ was used. After 24 hours of incubation, this pre-formed MDBK cell monolayer was infected with $0.5 \mathrm{~mL}$ of an $10^{7.5} \mathrm{TCID}_{50}$ $\mathrm{mL}^{-1}$ suspension of BoHV-1 (10 7,2 TCID50) per $150 \mathrm{~cm}^{2}$ flasks in $60 \mathrm{~mL}$ of infection medium, without adsorption step. The infection medium did not contain bovine foetal serum (BFS). Flasks were incubated at $37^{\circ} \mathrm{C}$ in $5 \% \mathrm{CO}_{2}$ (Thermo Electron Corporation, USA) until 80$90 \%$ of the cell monolayer was destroyed by the virus. This viral suspension was collected and centrifuged at 2160xg (PR-2 centrifuge; International Equipment Co., USA) for $15 \mathrm{~min}$ at $4^{\circ} \mathrm{C}$ for removal of cellular debris. Infectivity was determined in the supernatant and the viral titre was $10^{7,8} \mathrm{TCID}_{50} \mathrm{ml}^{-1}$. The final viral suspension was stored at $4^{\circ} \mathrm{C}$ until the inactivation. The clarified and titrated viral suspension was inactivated using $3 \mathrm{mM}$ (final concentration) binary ethylenimine (BEI) at $26^{\circ} \mathrm{C}$ (BAHNEMANN, 1990) for 24 hours. The inactivation was stopped by the addition of a $1 \mathrm{M}$ sterile Na-thiosulphate solution at $10 \%$ of the volume of the BEI solution used. The suspension was tested for residual infectivity by three consecutive passages of 5 days each in MDBK cultures $(1 \mathrm{~mL}$ of inactivated suspension in $25 \mathrm{~cm}^{2}$ flasks). The inactivated suspension was then adsorbed onto $20 \%$ aluminium hydroxide (produced by Vallée S.A, Brazil) as adjuvant at $4{ }^{\circ} \mathrm{C}$, for $12 \mathrm{~h}$. Each vaccine dose contained $4 \mathrm{~mL}$ of the inactivated viral suspension (total titre per dose: $10^{8,4} \mathrm{TCID}_{50}$ ) and $1 \mathrm{~mL}$ of adjuvant. No preservatives were added.

Experimental protocol

Seventeen cross-bred heifers, aged between 18 and 24 moths, seronegative for BoHV 1 (VN titer $\leqslant 2$ ), were divided in vaccinated group (12 animals) and unvaccinated control group (5 animals). Vaccinated heifers received $5 \mathrm{~mL}$ of the experimental vaccine subcutaneously, followed by an identical dose, 25 days later, also subcutaneously. Blood was collected at 0,9, $18,25,32,46,60,86,114,150,210,270$ and 330 days after the first vaccination and the serum was submitted to a temperature of $56^{\circ} \mathrm{C}$ for 30 minutes to inactivate the complement components; after that, it was frozen until the analysis. Nasal secretions were collected on 
cotton swabs (Inlab, Brazil) until 150 days postvaccination (DPV). After that, the swab was placed in appropriate tubes containing $1 \mathrm{~mL}$ of MEM with $1 \%$ antibiotic for transport to the laboratory. Tubes were agitated 30 seconds and centrifuged at $2160 \mathrm{~g}$ at $4{ }^{\circ} \mathrm{C}$ for 10 minutes, and the supernatant was frozen until analysis.

Evaluation of the humoral immune response

Neutralizing antibodies were measured by a standard virus neutralization assay as described by OIE (2008). Serum samples were tested in duplicate. For graphic representation of results, the $\mathrm{VN}$ antibody titres were transformed in $\log _{2} x+1$, in which $x$ is the $\mathrm{VN}$ antibody titre, because zero is not a valid value to calculate $\log 2$.

The general procedure described by the supplier of the ELISA kit for the detection of antibodies against Bovine Infectious Rhinotracheitis Virus (IDEXX, Westbrook, USA) was followed to measure the anti-BoHV-1 antibody isotypes in serum and nasal swab samples, except for the use of anti-bovine IgG1 or anti-bovine $\operatorname{IgG} 2$ peroxidase conjugates (Bethyl Laboratories, Montgomery, USA) to replace the antibovine total $\mathrm{IgG}$ peroxidase conjugate supplied in the kit. The optimal dilutions for anti-IgG1 and anti-IgG2 conjugates were determined by checkerboard titration using as diluent phosphate buffered saline (PBS) with $0.05 \%$ Tween 20 (Merck, Germany) and 1.5\% ovoalbumin (Sigma-Aldrich, USA). Pools of 6 negative, and 6 strong positive sera in the virus neutralizing test were used to standardize the controls for anti-BoHV-1 $\mathrm{IgG} 1$ and anti-IgG2 antibodies. The reading of optical densities (OD) was recorded in an ELISA Multiskan Ascent (Thermo Lasystems, USA) microplate reader at $650 \mathrm{~nm}$. The sample to positive values $(\mathrm{S} / \mathrm{P})$ was calculated by the following formula:

$S / P=Z-X / Y-X$ (Where $Z=O D$ of the test sample (serum or nasal secretion), $X=O D$ of the negative control, and $\mathrm{Y}=\mathrm{OD}$ of the positive control).

\section{Statistical analysis}

The Kruskall-Wallis non-parametric test was used for the analysis of neutralizing antibody titres and of S/P values of each antibody isotype and, when a significant difference between medians was evident, Dunn's non-parametric test was applied. Differences in $P$ value of $\leqslant 0.05$ were considered significant. Linear regression analysis was performed to determine the relationship between the two variables. Pearson's correlation coefficient was also calculated.

\section{RESULTS AND DISCUSSION}

Systemic virus-neutralizing antibody responses

Relevant anti-BoHV-1 VN antibody titres developed in serum of vaccinated animals remained at moderate to high levels from 25 to 210DPV (Figure 1). No relevant VN antibody titres were detected in nonvaccinated animals for the entire post-vaccination

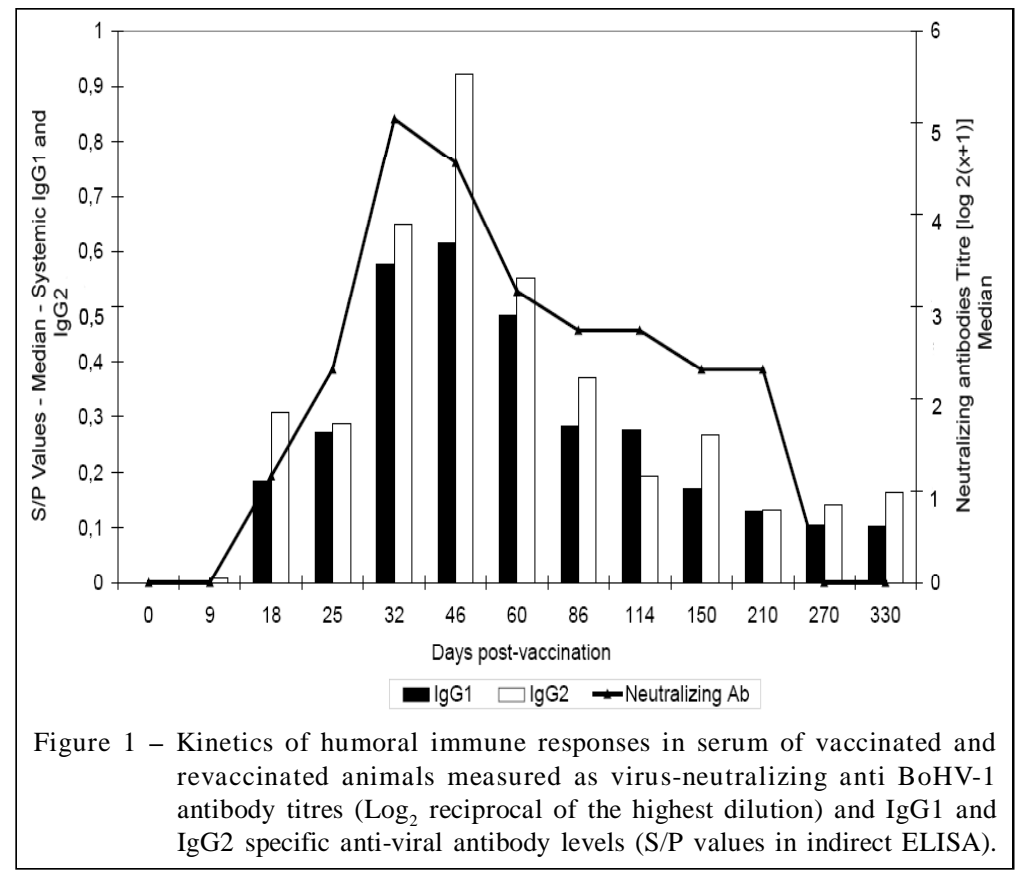

Ciência Rural, v.41, n.2, fev, 2011. 
period investigated. After the first vaccination, a maximum of $41.6 \%$ (5 out of 12 heifers) of the immunized animals showed a slight elevation of virus-neutralizing antibody production (Figure 1). The revaccination resulted in a significant rise in $\mathrm{VN}$-antibody titres, which was characterized by more than doubling in $\log _{2}$ of the antibody titres $(\mathrm{P}<0.01)$ (Figure 1). The anti-BoHV-1 median VN-antibody titres reached the acceptable threshold value ( $\geqslant \log _{2}=3$, according to Code of Federal Regulation, US, 2006) and remained at this level in $100 \%$ of the animals until 60DPV. The median VN antibodies began to decline towards slightly low titres $\left(\log _{2}=2.32 \leqslant V N\right.$ titres $\left.\leqslant \log _{2}=2.74\right)$, from 86 to $210 \mathrm{DPV}$, and became negative in the last two sampling times, 270 and 330DPV (Figure 1). The evolution of median VN antibody titres showed also that the highest percentages $(50-100 \%)$ of vaccinated animals harbouring acceptable levels of these antibodies $\left(\log _{2} \geqslant 3\right)$ were reached between 32 to $115 \mathrm{DPV}$ and declined afterwards to $25-33.3 \%$ (150-270DPV). These results, particularly the kinetic profile of the humoral immune response to BoHV-1, resembled to that found, either after the administration of one or two doses of inactivated vaccines (CAMPOS et al., 1990; FULTON et al., 1995). Despite the decline in neutralizing antibody titres, the possibility that animals might yet be protected against the clinical signs induced by an infection of the BoHV-1 cannot be rejected. It has been reported that vaccinated calves, even exhibiting low anti-BoHV-1 antibody titres, showed a peak in the antiviral antibodies in response to challenge performed after six months of vaccination, as a consequence of an anamnestic response that might have contributed to a significant reduction of respiratory clinical signs induced by the virus (PETERS et al., 2004). Additionally, the aluminium hydroxide used as adjuvant in the current investigation may have contributed to the early decline of anti-BoHV-1 neutralizing antibody titres, since its deposit effect is lower than f mineral oil (CAMPOS et al., 1990; FULTON et al., 1995). Based on these results, it should be recommended to revaccinate the animals every six months.

Systemic and local IgG1 and IgG2 anti-BoHV-1 antibody responses

As it was tested an inactivated BoHV-1 vaccine containing aluminium hydroxide, which is a good inducer of IgG antibody responses, but is not efficient in raising IgA antibodies (GUPTA, 1998), only IgG1 and IgG2 anti-BoHV-1 isotypes were evaluated in this study.

The first vaccine dose elicited a slight rise in the levels of systemic IgG1 and IgG2 antiviral antibodies, early as 18DPV, and the revaccination (25 DPV) induced a typical anamnestic response of both isotypes, which was characterized by a sharp increase in the levels of these antibody isotypes after 32 to 60DPV (Figure 1). The levels of IgG1 and IgG2 antibodies started to decline at 86DPV, maintaining moderate levels until 150DPV, and from this point on, these antibodies presented a marked reduction (210330DPV). The kinetics of the systemic response of anti BoHV-1 antibodies induced by the experimental vaccine demonstrated that the IgG2 prevailed over IgG1 isotype in vaccinated animals for most of the post-vaccination intervals analysed (Figure 1). The close relationship between anti-BoHV-1 VN antibody titres and IgG1 and IgG2 antibody levels was demonstrated by the similarity of the kinetic curves of these antibodies (Figure 1). Virus-neutralizing antibodies reached maximum concentration at 32DPV, whereas specific anti-virus antibodies of $\mathrm{IgG} 1$ and $\mathrm{IgG} 2$ isotypes showed the highest concentration at 46DPV (Figure 1). Nevertheless, there were no significant differences between concentrations of neutralizing antibodies at 32 and 46 DPV $(\mathrm{P}>0.05)$. Thus, the highest levels of anti-BoHV-1 antibodies of IgG1 and IgG2 isotypes coincided with the peak of neutralizing antibody activity. In addition to this, positive correlation coefficients were also found for $\mathrm{VN}$ antibody titres and IgG1 or IgG2 antibody levels, corresponding to $\mathrm{r}=0.865$, and $\mathrm{r}=0.779$, respectively. $\mathrm{IgG} 2$ was also the prevailing antibody in nasal secretions of vaccinated animals. This isotype peaked between $32-46 \mathrm{DPV}$, as well as relatively high levels of this immunoglobulin $(S / P \geqslant 0.5)$ were detected in most of the time points investigated (25, 60,86 , and 114DPV), as occurred with the systemic antibodies of this isotype. In contrast, IgG1 antibodies appeared in detectable and significant amounts $(\mathrm{S} / \mathrm{P} \geqslant 0.5)$ only at 32 and 46DPV (Figure 2$)$. A positive correlation between nasal and circulating IgG1 and $\mathrm{IgG} 2$ antibody levels was also found ( $\mathrm{r}=0.66$ and 0.866, for $\mathrm{IgG} 1$ and $\operatorname{IgG} 2$, respectively, $\mathrm{P}<0.001$ ), suggesting that there was, at least, a partial transference of these antibodies from systemic to the local compartment, especially for IgG2 antibodies.

The IgG2 isotype showed similar kinetic profiles with regard to those found in serum from of antibody-free calves experimentally infected with BoHV-1 (MADIC et al., 1995). Moreover, the levels of anti-BoHV-1 systemic IgG2 antibodies compared to IgG1 isotype remained higher. These results differ from MADIC et al. (1995) where IgG1 isotype prevailed over $\mathrm{IgG} 2$. However, the reason for the prevalence of $\mathrm{IgG} 2$ antibodies is unclear, since the regulation of the immune response for the production of a specific 


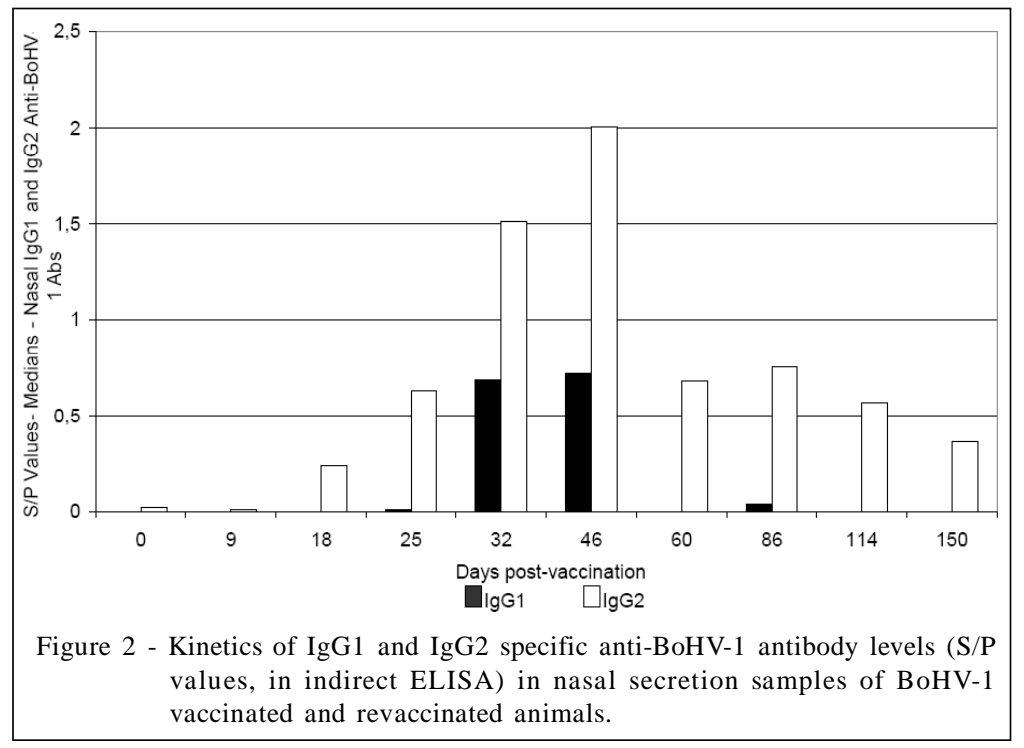

immunoglobulin isotype is a complex process dependent upon many factors and several parameters may influence the formation of immunoglobulin isotypes, such as the macromolecular form of the immunogen, type of antigen, and the adjuvant used, as demonstrated in the experimental immunization of calves against foot-and-mouth disease virus (MULCAHY et al., 1990).

The protective capacity of each antibody isotype may be interpreted according to its biological activity and, consequently, to its capacity to interact with various immune effector cells or humoral factors, as well as the role of these cells in conferring protection against the pathogen (MULCAHY et al., 1990). Regarding the immune-protection against BoHV-1, antibodies of isotype $\mathrm{IgG} 2$ display greater opsonizing activity than those of isotype IgG1 for bovine neutrophils present in peripheral blood (HOWARD et al., 1980; PETERS et al., 2004), thus indicating that there is greater affinity of the receptors of these cells for $\mathrm{IgG} 2$ antibodies. On the other hand, antibodies of isotype $\operatorname{IgG} 1$ are able to efficiently mediate the phagocytosis process in bovines by mononuclear phagocytes such as macrophages, rather than neutrophils, because these cells express higher numbers of receptors or greater affinity of their receptors for the IgG1 Fc region (HOWARD et al., 1980; MULCAHY et al., 1990). Considering that ADCC constitutes one of the main mechanisms involved in immunity to BoHV-1, and neutrophils are the cells more directly involved in this process (BABIUK et al., 1996), it was suggested that antibodies of $\mathrm{IgG} 2$ isotype induced by the inactivated experimental BoHV-1 vaccine in the current study may play an important role in immunity against this virus.

The correlation between concentrations of anti-BoHV-1 IgG1 and IgG2 antibodies in serum and nasal secretion is not an unexpected result, since it has been demonstrated that the intramuscular administration of a subunit vaccine consisting of BoHV-1 glycoproteins is capable of inducing neutralizing antibodies in the nasal mucosa of immunized bovines (BABIUK et al., 1987). Furthermore, the vaccinated animals demonstrated the protection against replication of the viral pathogen associated with neutralizing antibody titres in the nasal secretion, and these local antibodies, in turn, showed a high level of correlation with serum antibody titres (BABIUK et al., 1987). Therefore this finding supports the hypothesis of selective transportation of $\operatorname{IgG} 2$ isotype from serum to the nasal mucosa, and indicates that the concentration of such anti-BoHV-1 antibodies in the mucosa, at least in part, depends upon specific anti-BoHV-1 antibodies present in serum (BABIUK et al., 1987).

Systemic and local $\mathrm{IgG} 1$ and $\mathrm{IgG} 2$ antiBoHV-1 antibody responses induced by the administration of an experimental inactivated vaccine were well characterized in the current investigation, but the functions of different antibody isotypes in cattle, relative to the specific mechanisms of protection against BoHV-1, need further investigation. Inactivated vaccines, particularly those containing aluminium hydroxide adjuvant, may not be expected to result in a significant cell-mediated immunity or an extensive production of $\operatorname{IgA}$ antibodies in the mucosa (McGHEE et al., 1992; GUPTA, 1998). Conversely, the aluminium 
hydroxide does stimulate the production of neutralizing $\mathrm{IgG}$ antibodies, particularly from $\mathrm{IgG} 2$ isotype, as demonstrated here, and they are distributed in blood and in the nasal secretion and may thus block BoHV-1 replication at the initial infection site, as proposed before (ZHU \& LETCHWORTH, 1996). However, an important point to be emphasized is the brief half-life of such antibodies in the nasal secretion (Figure 2), making local antibody levels decrease shortly after revaccination.

\section{CONCLUSION}

Systemic and local anti-BoHV-1 antibody responses were induced by the experimental inactivated vaccine in the current study. Neutralizing anti-BoHV-1 antibodies were achieved in potentially protective titres until $86 \mathrm{DPV}$ and $\mathrm{IgG} 1$ and $\mathrm{IgG} 2$ antibody responses were induced after the second vaccination in the serum and in nasal secretions up to 114 days post vaccination. IgG2 antibodies were the prevalent isotype for most of the post-vaccination period. Despite not evaluated in the context of protection against experimental infection, the vaccineinduced antibodies can be used as markers for monitoring the effect of the immunization against this virus in cattle, as well as the presence of anti-BoHV-1 IgG1 and IgG2 antibodies in serum and nasal secretion from bovines immunized with inactivated vaccines. If the isotypes found in the current study may substantiate other effectors mechanisms at the main virus entry site, in addition to the virus neutralization, further investigation are required.

\section{ACKNOWLEDGEMENTS}

The authors would like to thank Vallée S.A. that supported this research and provided reagents and adjuvants and Faculdade de Ciências Agrárias e Veterinárias (UNESP) for the animals used.

\section{BIOETHICS AND BIOSSECURITY COMMITTEE APPROVAL}

The animals used on this research were approved by the Commission of Ethics in Animal Experimentation (CEAE) of ICB-USP - Protocol number 111, registered on page 10 of Book 2, approved on 01 February, 2005.

\section{REFERENCES}

BABIUK, L.A. et al. Protection of cattle from bovine herpesvirus type I (BHV-1) infection by immunization with individual viral glycoproteins. Virology, v.159, p.57-66, 1987.

BABIUK, L.A. et al. Immunology of bovine herpesvirus 1 infection. Veterinary Microbiology v.53, p.31-42, 1996.
BAHNEMANN, H.G. Inactivation of viral antigens for vaccine preparation with particular reference to the application of binary ethylenimine. Vaccine, v.8, p.299-303,1990.

BRADSHAW, B.J.F.; EDWARDS, S. Antibody isotype responses to experimental infection with bovine herpesvirus 1 in calves with colostrally derived antibody. Veterinary Microbiology, v.53, p.143-151, 1996.

CAMPOS, E. et al. Comportamiento de una vacuna a virus vivo modificado y de una vacuna inactivada en el control de la rinotraqueitis infecciosa bovina. Veterinaria Tropical, v.15, p.109-125, 1990.

FLORES, E.F. (organizador). Virologia veterinária. Santa Maria: UFSM, 2007. 888p.

FULTON, R.W. et al. Antibody responses by cattle after vaccination with commercial viral vaccines containing bovine herpesvirus 1 , bovine viral diarrhea virus, parainfluenza- 3 virus and bovine respiratory syncytial virus immunogens and subsequent revaccination at day 140 . Vaccine, v.13, p.725733,1995 .

GUPTA, R.K. Aluminium compounds as vaccine adjuvants. Advanced Drug Delivery Reviews, v.32, p.155-172, 1998.

GUY, J.S.; POTGIETER, L.N.D. Bovine herpesvirus-1 infection of cattle: kinetics of antibody formation after intranasal exposure and abortion induced by the virus. American Journal of Veterinary Research, v.46, p.893-898, 1985.

HOWARD, C.J. et al. Surface receptors for immunoglobulin on bovine polymorphonuclear neutrophils and macrophages. Research in Veterinary Science, v.29, p.128-130, 1980.

JONES, C.; CHOWDHURY, S. A review of the biology of bovine herpesvirus type 1 (BHV-1), its role as a cofactor in the bovine respiratory disease complex and development of improved vaccines. Animal Health Research Reviews, v.8, n.2, p.187-205, 2008 .

LEMAIRE, P. et al. Le contrôle de l' infection par le virus de la rhinotrachéite infectieuse bovine. Annales de Médicine Vétérinaire, v.138, p.167-180, 1994.

MADIC, J. et al. Isotype-specific antibody responses in sera and mucosal secretions of calves experimentally infected with bovine herpesvirus 1. Veterinary Immunology and Immunopathology, v.46, p.267-283, 1995.

MCGHEE, J.R. et al. The mucosal immune system: from fundamental concepts to vaccine development. Vaccine, v.10, p.75-78, 1992.

MCGUIRE, T.C. et al. Functional properties of bovine IgG1 and $\operatorname{IgG2:}$ interaction with complement, macrophages, neutrophils and skin. Immunology, v.38, p.249-256, 1979.

MULCAHY, G. et al. Isotype responses of infected, virusvaccinated and peptide-vaccinated cattle to foot-and-mouth disease virus. Vaccine, v.8, p.249-256, 1990.

MUYLKENS, B. et al. Bovine herpesvirus 1 infection and bovine rhinotracheitis. Veterinary Research, v.38, p.181209, 2007. 
OIE World Organization for Animal Health, 2008. Manual of standards for diagnostic tests and vaccines for terrestrial animals. Infectious Bovine Rhinotracheitis/ Infectious Pustular Vulvovaginitis. Paris, 2008. Chapt.2.4.13, 752767. (OIE Terrestrial Manual). Available from: http://www.oie.int/eng/ normes/mmanual/2008/pdf/2.04.13_IBR_IPV.pdf. Accessed: Mar 18, 2008.

PETERS, A.R. et al. Duration of immunity of a quadrivalent vaccine against respiratory diseases caused by BHV-1, PI3V, BVDV and BRSV in experimentally infected calves. Preventive Veterinary Medicine, v.66, p.63-77, 2004.

U.S. Department of Agriculture (2006). 113.310 Bovine rhinotracheitis vaccine. Code of Federal Regulation. Office of the Federal Register
National Archives and Records Administration, sec. 113.216, Title 9, v. 1, Government Printing Office via GPO Access, Washington, D.C., 657-658. Available at: <http://frwebgate1.access.gpo.gov/cgi-bin/ PDFgate.cgi?WAISdocID=HelvIY/64/2/0\&WAISaction=retrieve >. Accessed: Mar 18, 2008.

VAN DRUNEN LITTEL-VAN DEN HURK, S. et al. A subunit gIV vaccine, produced by transfected mammalian cells in culture, induces mucosal immunity against bovine herpesvirus-1 in cattle. Vaccine, v.12, p.1295-1302, 1994.

ZHU, X.; LETCHWORTH III, G.J. Mucosal and systemic immunity to bovine herpesvirus-1 glycoprotein D confers resistance to viral replication and latency in cattle. Vaccine, v.14, p.61-69, 1996. 